\title{
MANAGEMENT, CLIMATIC LIMITATIONS AND POTENTIALS FOR PRODUCTION IN THE WAIRARAPA
}

\author{
John D. McDougaLl \\ "Sunnyside", M nrtinborough
}

THIS PAPER will give a brief description of the property "Sunnyside", its development and management, and outline the climatic limitations, which are an erratic and poorly distributed rainfall and strong drying winds from the north-west.

"Sunnyside" is 3,550 acres predominantly hill country, situated 11 miles due south of Martinborough. Average annual rainfall is 50 in, The soil is mostly mudstone with Taihape silt loam (Type 114A) being the largest defined area. The altitude varies from 300 to $1,200 \mathrm{ft}$.

In 1959 when I took over this property from my family, it carried 5,000 Romney ewes to the Southdown ram and 500 bullocks, a stocking rate of just over 2 ewe equivalents per acre. All lambs were drafted and sold early in January, the big majority fat. Virtually no topdressing had been done, but pastures were in good condition owing to excellent grazing management over the years. White clover and ryegrass had survived from the original hand sowing where fertility and moisture allowed. Wool production averaged $16 \mathrm{lb}$ per acre.

During the first five years, nearly 800 tons of fertilizer was spread, half of it in 1963. Progress was slow and sheep numbers rose by only 1,500 .

Lack of confidence to tackle the physical, financial and management problems was the main barrier. In the $51 / 2$ years since 1963 , stock units have nearly doubled. The whole farm has now been oversown and has had a capital fertilizer dressing of between 8 and $10 \mathrm{cwt}$. Sheep numbers have increased by a further 8,000 , including 3,500 ewe hoggets which are all mated and produce up to $50 \%$ of lambs. A flock of interbred Border-Romney ewes has been established and about $40 \mathrm{lb}$ of wool per acre is now grown.

Cattle numbers have remained static because it appeared that the first priority was to reach the optimum stocking rate as 
quickly and cheaply as possible, and the high capital input of cattle opposed this objective.

During the latter stages of this development, it has become apparent that two dressings of 4 to $5 \mathrm{cwt}$ of superphosphate and a well-planned and executed oversowing of 5 to $6 \mathrm{lb}$ of white clover can be expected to lift carrying capacity from just over 2 to 5 ewe equivalents per acre over a two-year period, provided one is happy with five relatively thin ewes instead of two fat ones.

The total stock increases may seem impressive but the scale confuses the issue. Adjust them to a 3,550 acre property and they become only mediocre.

Subdivision and water supply lagged behind, and the initial oversowing was poorly planned and executed; insufficient attention was paid to timing and seedbed preparation, and much may have to be resown. It is vital to achieve a good strike and survival with the initial oversowing and to be able to graze the area properly after this is done.

Paddock size and water supply are limiting factors to grazing management. Pasture and stock management at the higher stocking rates are only now becoming vaguely understood. Hard experience demonstrated that a paddock that would winter five ewes would not carry four ewes and one ewe equivalent of cattle. The sheep merely eat more, get too fat, and the cattle starve. The cows and ewes graze the larger steeper paddocks, and the ewe hoggets and young cattle graze the easier country.

Th cows and ewes run together during the summer and about mid-April they are placed on a restricted diet with some paddocks shut up for the cows later on. The cows are left with the ewes until the last possible moment, then shifted to their saved paddocks and wintered on their own.

Ideally, ewe hoggets and young cattle would be wintered together on good nutritious pasture which is not too short. Short grass and intensive grazing, although suited to ewes, do not seem to produce the high growth rates being sought in the hoggets.

In the early stages a total of 500 acres were cultivated. The sown grass appears to be little, if any, more productive, but it is useful to be able to drive around the flats and the high-quality summer feed is good for young stock.

Nearly 1,000 tons of lime was spread. The expenditure on cultivation and lime would probably have given more immediate returns if it had been spent on superphosphate, stock, fencing and water supplies. 


\section{MANAGEMENT}

There is only one house on the farm and the staff travel from town each day. "Sunnyside" is run as three units with a submanager on each. There are two 2-man blocks and one 1-man block, a very competitive situation. This allows about 3,000 ewe equivalents per labour unit. It is possible and necessary to do much better than this and to this end all labour inputs are being recorded and analysed. Already some interesting information has resulted. For example, more time is being spent per ewe equivalent on cattle than on sheep. This probably reflects the smaller mob size of cattle relative to sheep handled.

Although there are $41 / 2$ miles of metalled internal road, 3 miles of central lane way, and 8 sets of permanent yards, all can be justified, and will be increased. Four years ago the woolshed was rebuilt in a central position; this has proved very. worth while. There is increasing reliance on motorbikes, a "Gnat", and the car to maintain mobility.

Nearly three years ago the farm adviser, D. Todd, suggested investigation, on a small scale, of the effects on both animals and pasture of pushing stocking rate to the existing upper limits. A 64-acre paddock was set-stocked, since this seemed to be the management trend, at 7 ewes per acre. The ewes became poor; their wool and lamb production slipped about $20 \%$, and lamb "mortality at birth rose. During the second season the rate was increased to 9 ewes per acre during the autumn but this proved to be. the straw that broke the camel's back. Some ewes became physically weak but, surprisingly, others remained in good condition. Since yield per acre is the aim, the crucial question is did they eat more or require less? This brings up the vital question of utilization and conversion rate. However, it was very reassuring to see how far one could go without ewe mortality rising significantly.

It is anticipated that the stocking rate will tend to stabilize for a while now at "Sunnyside". If more capital stock are not required, it is planned, during the next five years, to increase cattle from 550. to 2,200 while reducing sheep from 15,000 to 9,000.

Profitability, flexibility, better labour utilization and improved sheep performance are the objectives. The availability of finance and lack of experience of running cattle at high stocking rates will dictate the rate of change.

It is intended to remain "all-grass" farmers if possible and be prepared to take losses in the market when necessary, rather 
TABLE 1: COMPARATIVE SEASONAL RAINFALL DISTRIBUTION

Jan. Feb. March April May June July Aug. Sep. Oct. Nov. Dec. Total

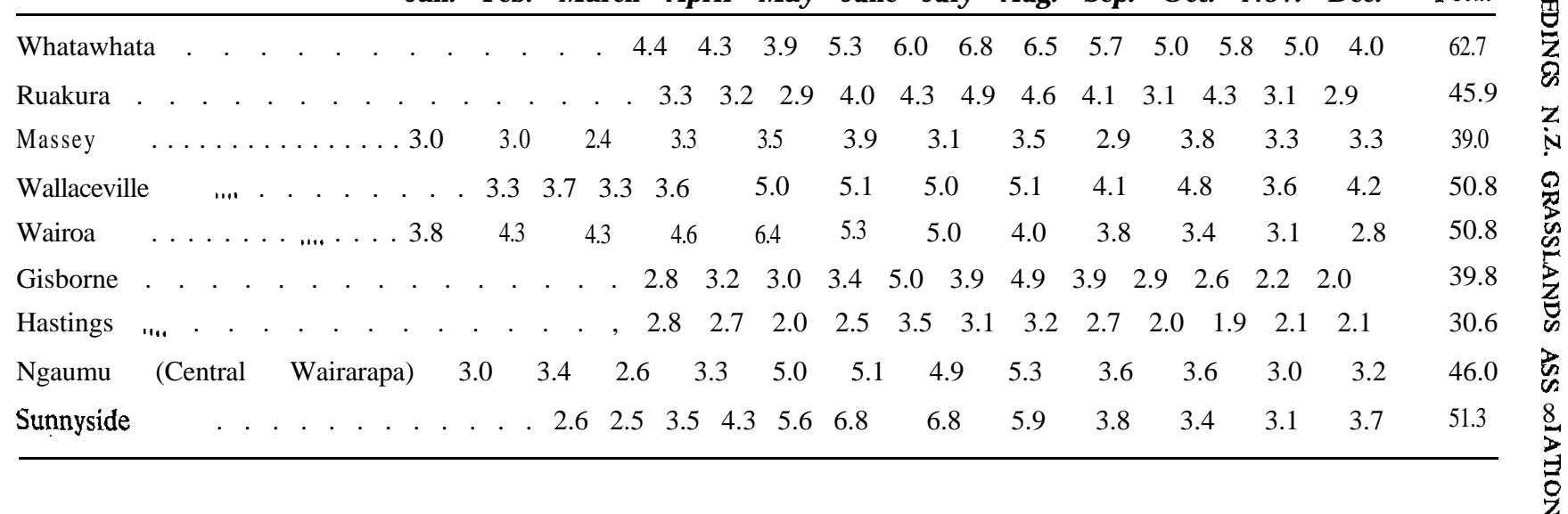


than become involved in supplementary feeding with its attendant costs.

To sum up the present position: Although on paper the farm is carrying nearly 5 ewe equivalents per acre, the gross stock margin, during these last 'two droughty years, has averaged only $\$ 23$ per acre. This could be achieved by 4 well-fed ewe equivalents.

Available evidence suggests that yield per animal can readily be increased, 20\%: genetically by breeding and culling, and another $20 \%$ by better management and controlled feeding without reducing stocking rate. However, I believe we are at least $1 \frac{1 / 2}{2}$ ewe equivalents below what one would expect to 'achieve at a similar nutritional level on similar soil and altitude on the western side of the island, where unfortunately, all the major agricultural research facilities are, except Ballantrae, which, although on the eastern side of the ranges,, is climatically not typical of the east coast.

The special problems on this side of the "-island are erratic and poorly distributed rainfall and strong drying winds from the north-west - see Tables 1 and 2 .

As can be seen from Table 2, unlike most other droughty areas, there is liable to be either a feast or a famine. This poses very real management problems. If one stocks up for pasture control in an average year, the stock can suffer badly in a poor year.

This combination of erratic rainfall and drying wind makes itself felt most during the September-October and FebruaryMarch periods. Like much of the east coast "Sunnyside" has water problems, regarding both quantity and quality, but these can be overcome at a price. Supplementary feeding on the hills in drought conditions is easy compared with winter feeding with its associated mud and transport difficulties. So the physical aspects of keeping stock alive in a drought do not present a big hurdle.

This is not, however, the complete answer. The SeptemberOctober downturn restricts lactation and holds lambs back and can also make cattle feed short during the summer, while the February-March downturn reduces the ovulation rate of the ewes. However, the late autumn growth creates the biggest single problem. The period of rapid growth is just too short to allow the grass to get ahead of the stock before the winter.

The worst effects of drought are therefore likely to occur when the $7 \mathrm{in}$. of rain per month fall during the following winter, 
TABLE 2: VARIABILITY OF TOTAL RAINFALL FOR THE SIX MONTH PERIOD OCTOBER TO MARCH AT SUNNYSIDE

\begin{tabular}{|c|c|c|c|c|c|c|c|c|c|c|c|}
\hline 1949 & $\ldots$ & $\ldots$ & "וי. & $\ldots$ & 16 & 1959 & $\ldots$ & $\ldots$ & $\ldots$ & $\ldots$ & 18 \\
\hline 1950 & $\ldots$ & $\ldots$ & .... & $\ldots$ & 23 & 1960 & $\ldots$ & $\ldots$ & $\ldots$ & $\ldots$ & 19 \\
\hline 1951 & $n$ & $\ldots$ & $\ldots$ & $\ldots$ & 23 & 1961 & $\ldots$ & $\ldots$ & $\ldots$ & $\ldots$ & 12 \\
\hline 1952 & $\ldots$ & $\ldots$ & .... & $\ldots$ & 26 & 1962 & $\ldots$ & $\ldots$ & $\ldots$ & $\ldots$ & 19 \\
\hline 1953 & . . & . . & . . . & $\ldots$ & 22 & 1963 & $\ldots$ & $\ldots$ & $\ldots$ & $\ldots$ & 13 \\
\hline 1954 & $\ldots$ & $\ldots$ & $\ldots$ & $\ldots$ & 22 & 1964 & $\ldots$ & ..101 & $\ldots$ & $\ldots$ & 11 \\
\hline 1955 & $\ldots$ & $\ldots$ & $\ldots$ & $\ldots$ & 11 & 1965 & $\ldots$ & ..... & $\ldots$ & $\ldots$ & 23 \\
\hline 1956 & $\ldots$ & $\ldots$ & $\ldots$ & $\ldots$ & 23 & 1966 & $\ldots$ & $\ldots$ & $\ldots$ & $\ldots$ & 26 \\
\hline 1957 & $\ldots$ & $\ldots$ & $\ldots$ & $\ldots$ & 14 & 1967 & "x! & $\ldots$ & $\ldots$ & $\ldots$ & 21 \\
\hline \multirow[t]{2}{*}{1958} & $\ldots$ & $\ldots$ & $\ldots$ & $\ldots$ & 19 & 1968 & . & . . ... & $\ldots$ & . . & 13 \\
\hline & & & Aver & & & $\ldots$ & $\ldots$ & 19 & & & \\
\hline
\end{tabular}

Answers to the following problems would benefit the farmer in Wairarapa:

(1) Are the pasture species developed on the west coast suited to this climate?

(2) Would space-planting of poplars at chain centres improve the microclimate at an economic cost?

(3) More knowledge is required of trace element deficiencies and the inter-relationship of such minerals as molybdenum, copper and selenium?

(4) What are maintenance fertilizer requirements and when would the use of nitrogen be an economic proposition?

(5) Would high cattle stocking rates break down soil structure, as the Wairarapa Catchment Board suggests?

Farm advisory officers from the Department of Agriculture are drawing up a water reticulation plan for "Sunnyside" at a probable cost of $\$ 7$ to $\$ 8$ per acre. For this cost $(\$ 25,000), 120$ open dams, or one to every 30 acres, can be built in addition to the existing dams. With this number of dams, it is possible that fouling would be reduced to an acceptable level.

Both as an industry and a nation, our expenditure on research is insufficient; we are in danger of being left behind. I suggest that increased expenditure on research into the problems outlined would prove to be very rewarding,

What will be the next leap forward? Perhaps better pasture species and establishment, possibly aided by chemical seedbed preparation or other new techniques, establishment of a superior microclimate, and new and improved soil nutrient supply. 
If the limitations imposed by the erratic rainfall and wind can be overcome there seems no reason why productivity cannot be raised to the high levels being achieved at Whatawhata, Massey and Ruakura.

\section{DISCUSSION}

To a question regarding the ability of poplars to grow in very strong winds prevailing at "Sunnyside", McDougall replied that there was some difficulty, However, he felt it could be overcome to some extent by using suitable species and better planting methods and by planting from the bottom of a valley upwards so that the more recently planted poles received some protection.

Kerr commented that Plant Physiology Division, DSIR, was starting a programme to study evapotranspiration for a wide range of crops in the field. It was hoped that the proportion of water used by sun energy and wind energy could be estimated. These studies would be related with others to be carried out in controlled climate cabinets so that some answers to the water relationship problem should be available in a few years.

Lancashire thought that there was a need for water conservation measures during wet periods to cushion the 'effects of shortage during droughts. McDougall agreed that this would be valuable but thought that the eroded valleys would make it difficult to store water and then return it to the areas where it was needed.

Brougham questioned whether farmers were acquainting themselves sufficiently with research which had already been carried out, before suggesting that more research stations should be set up in Wairarapa. Falloon commented that Grasslands Division scientists had helped him tremendously at "Pukunui" and that their advice had been most helpful and much appreciated. 